\title{
The association between gastric acid inhibitors and delirium in geriatric inpatients: implications for clinical practice and research
}

\author{
Ling-ling Zhu' \\ Quan Zhou ${ }^{2}$ \\ 'VIP Care Ward, Division of Nursing, \\ the Second Affiliated Hospital, \\ School of Medicine, Zhejiang \\ University, Hangzhou, Zhejiang \\ Province, People's Republic of China; \\ ${ }^{2}$ Department of Pharmacy, the \\ Second Affiliated Hospital, School \\ of Medicine, Zhejiang University, \\ Hangzhou, Zhejiang Province, People's \\ Republic of China
}

This article was published in the following Dove Press journal:

Clinical Interventions in Aging

16 June 2016

Number of times this article has been viewed

\section{Dear editor}

We read with great interest the prospective observational study by Otremba et al, ${ }^{1}$ which shows that use of proton-pump inhibitors (PPIs) is one of independent factors associated with development of delirium in geriatric inpatients (odds ratio $[\mathrm{OR}]=1.67$; confidence interval $[\mathrm{CI}]=1.11-2.53 ; P=0.014)$. We especially appreciate their new finding, because PPIs are commonly prescribed in older hospitalized patients. However, we found two points worthy of discussion and we would like to share our perspectives in the following paragraphs.

Firstly, Fujii et al reported that delirium incidence was significantly higher in patients receiving histamine- 2 receptor antagonists (H2RA) than in patients receiving PPIs (OR=3.82; $\mathrm{CI}=1.15-12.71, P=0.047)$ and they suggested that switching gastric acid inhibitors from H2RA to PPIs could provide an appropriate coping method for drug-induced delirium. ${ }^{2}$ Otremba et al's study will drive clinicians to pay more attention to pharmacotherapeutic monitoring of neuropsychiatric complication during PPI treatment duration.

Secondly, although Otremba et al discussed the mechanism behind the PPI and geriatric delirium association from multiple perspectives including a very brief mention of potential drug-drug interaction (DDI) between PPI and other drugs (eg, benzodiazepines and antidepressants), they did not demonstrate more details on the DDI aspect. Herein, we would like to further discuss it. Different from other benzodiazepines, diazepam is susceptible to cytochrome P450 2C19 (CYP2C19) inhibition. ${ }^{3}$ We have shown that different PPI has different risk of CYP2C19-mediated DDI and omeprazole has a greater risk for DDI with diazepam compared with other PPIs (eg, esomeprazole, pantoprazole, lansoprazole, and rabeprazole). ${ }^{4,5}$ So it is worthy to investigate the association of omeprazole versus other PPIs with delirium risk in geriatric inpatients receiving diazepam. Antidepressants also exhibit different risk of DDIs with PPIs. The effect of co-medicated PPIs on the serum concentration of selective serotonin reuptake inhibitors is more pronounced for omeprazole and esomeprazole than for lansoprazole and pantoprazole, whereas escitalopram, rather than citalopram and sertraline, is more susceptible to omeprazole and esomeprazole. ${ }^{6}$ Therefore, inappropriate drug combinations of PPI-benzodiazepine or PPI-antidepressants is an element worthy of consideration when evaluating specific factors for development of delirium in elderly patients. 


\section{Disclosure}

The authors report no conflicts of interest in this communication.

\section{References}

1. Otremba I, Wilczyński K, Szewieczek J. Delirium in the geriatric unit: proton-pump inhibitors and other risk factors. Clin Interv Aging. 2016;11: 397-405.

2. Fujii S, Tanimukai H, Kashiwagi Y. Comparison and analysis of delirium induced by histamine $\mathrm{h}(2)$ receptor antagonists and proton pump inhibitors in cancer patients. Case Rep Oncol. 2012;5:409-412.

3. Andersson T, Miners JO, Veronese ME, Birkett DJ. Diazepam metabolism by human liver microsomes is mediated by both S-mephenytoin hydroxylase and CYP3A isoforms. Br J Clin Pharmacol. 1994;38:131-137.
4. Li W, Zeng S, Yu LS, Zhou Q. Pharmacokinetic drug interaction profile of omeprazole with adverse consequences and clinical risk management. Ther Clin Risk Manag. 2013;9:259-271.

5. Zhou Q, Yan XF, Zhang ZM, Pan WS, Zeng S. Rational prescription of drugs within similar therapeutic or structural class for gastrointestinal disease treatment: drug metabolism and its related interactions. World $J$ Gastroenterol. 2007;13:5618-5628.

6. Gjestad C, Westin AA, Skogvoll E, Spigset O. Effect of proton pump inhibitors on the serum concentrations of the selective serotonin reuptake inhibitors citalopram, escitalopram, and sertraline. Ther Drug Monit. 2015;37:90-97.3 


\section{Author's reply \\ Iwona Otremba \\ Krzysztof Wilczyński \\ Jan Szewieczek}

Department of Geriatrics, School of Health Sciences in Katowice, Medical University of Silesia, Katowice, Poland

Correspondence: Jan Szewieczek

Department of Geriatrics, School of Health Sciences in Katowice, Medical University of Silesia, GCM, ul Ziolowa 45/47, 40-635,

Katowice, Poland

Tel +48 323598239

Fax +48322059483

Email jszewieczek@sum.edu.pl

\section{Dear editor}

In their letter, Ling-ling Zhu and Quan Zhou added several new perspectives concerning our recently published study on delirium risk factors in the geriatric ward and specifically gastric acid inhibitors as independent risk factors. We share the opinion that increased vigilance is warranted when prescribing proton-pump inhibitors (PPIs) and monitoring their adverse reactions. PPIs are considered more effective than histamine-2 receptor antagonists and relatively safe. ${ }^{1-3}$ Consequently, these medications are prescribed for elderly patients at an increasing rate, frequently as long-term medication without evidence-based indications. ${ }^{4}$ In our study population, $25 \%$ of patients were treated with PPIs while very few were treated with histamine-2 receptor antagonists. Increased use has revealed a more comprehensive adverse effect profile of PPIs, ${ }^{5}$ which includes potential risk factors for delirium in elderly patients. We also agree that PPI in-class differences, not analyzed in our paper, should be considered in future studies as well as taken into account in clinical practice.

\section{Disclosure}

The authors report no conflicts of interest in this communication.

\section{References}

1. Earnest DL, Robinson M. Treatment advances in acid secretory disorders: the promise of rapid symptom relief with disease resolution. Am J Gastroenterol. 1999;94:S17-S24.

2. Welage LS, Berardi RR. Evaluation of omeprazole, lansoprazole, pantoprazole, and rabeprazole in the treatment of acid-related diseases. J Am Pharm Assoc (Wash). 2000;40:52-62.

3. Huang JQ, Hunt RH. Pharmacological and pharmacodynamic essentials of H(2)-receptor antagonists and proton pump inhibitors for the practising physician. Best Pract Res Clin Gastroenterol. 2001;15:355-370.

4. Rane PP, Guha S, Chatterjee S, Aparasu RR. Prevalence and predictors of non-evidence based proton pump inhibitor use among elderly nursing home residents in the US. Res Social Adm Pharm. Epub 2016 Mar 8.

5. Schoenfeld AJ, Grady D. Adverse Effects Associated With Proton Pump Inhibitors. JAMA Intern Med. 2016;176:172-174.

Dove Medical Press encourages responsible, free and frank academic debate. The content of the Clinical Interventions in Aging 'letters to the editor' section does not necessarily represent the views of Dove Medical Press, its officers, agents, employees, related entities or the Clinical Interventions in Aging editors. While all reasonable steps have been taken to confirm the content of each letter, Dove Medical Press accepts no liability in respect of the content of any letter, nor is it responsible for the content and accuracy of any letter to the editor.

\section{Publish your work in this journal}

Clinical Interventions in Aging is an international, peer-reviewed journal focusing on evidence-based reports on the value or lack thereof of treatments intended to prevent or delay the onset of maladaptive correlates of aging in human beings. This journal is indexed on PubMed Central, MedLine,
CAS, Scopus and the Elsevier Bibliographic databases. The manuscript management system is completely online and includes a very quick and fair peer-review system, which is all easy to use. Visit http://www.dovepress. com/testimonials.php to read real quotes from published authors. 